\title{
Editorial \\ Circulating tumor cells in blood of primary breast cancer patients assessed by a novel RT-PCR test kit and comparison with status of bone marrow-disseminated tumor cells
}

\author{
Manfred Schmitt ${ }^{1}$ and John A Foekens ${ }^{2}$
}

\author{
${ }^{1}$ Clinical Research Unit of the Department of Obstetrics and Gynecology, Technische Universitaet Muenchen, Klinikum rechts der Isar, \\ Ismaninger Strasse 22, D-81675 Munich, Germany \\ 2Department of Medical Oncology, Erasmus Medical Center - Josephine Nefkens Institute and Cancer Genomics Centre, Postbus 2040, \\ 3000 CA Rotterdam, The Netherlands
}

Corresponding author: Manfred Schmitt, manfred.schmitt@|rz.tum.de

Published: 9 October 2009

Breast Cancer Research 2009, 11:109 (doi:10.1186/bcr2405)

This article is online at http://breast-cancer-research.com/content/11/5/109

(c) 2009 BioMed Central Ltd

See related research article by Fehm et al., http://breast-cancer-research.com/content/11/4/R59

\begin{abstract}
In breast cancer, circulating tumor cells (CTCs)/disseminated tumor cells (DTCs) may serve as independent adverse prognostic variables, to monitor the course of the disease and to predict response or failure to cancer therapy. Most of the techniques to enumerate DTCs in the bone marrow or CTCs in the bloodstream of breast cancer patients rely on a combination of an enrichment step and a detection step. A novel RT-PCR method, the AdnaTest BreastCancer ${ }^{\mathrm{TM}}$ kit, was developed for the enrichment of CTCs from peripheral blood of breast cancer patients followed by identification of CTC-associated marker transcripts by reverse transcription and PCR. Although this test has been demonstrated to identify breast cancer patients at risk, standardization of this technique and direct comparison with other established breast cancer CTC enrichment and detection techniques is still lacking, but highly needed. This is done best within prospective clinical trials, such as in the ongoing DETECT, SUCCESS, and BR-01-2004 trials.
\end{abstract}

In the previous issue of Breast Cancer Research, Fehm and colleagues evaluated the correlation between circulating tumor cells (CTCs) and disseminated tumor cells (DTCs) in the bone marrow of patients afflicted with primary breast cancer [1]. For this, the authors investigated blood samples from 431 patients for the presence of CTCs by assessing mRNA expression of epithelial cell-associated transcripts EpCAM, MUC1, and HER2, employing the novel AdnaTest BreastCancer $^{\mathrm{TM}}$ kit (AdnaGen AG, Langenhagen, Germany). The mRNA expression of receptors for the steroid hormones estrogen and progesterone was determined via accompanying in-house RT-PCR tests.

The DTC status was examined in the bone marrow of 414 patients by immunocytochemistry, using the pan-cytokeratin antibody A45-B/B3. CTCs were detected in $13 \%$ of the patients and DTCs were detectable in $24 \%$ of the patients [1]. The presence of DTCs in the bone marrow only weakly correlated with the presence of CTCs in the blood. CTCs were mostly found in triple-negative tumors (negative for estrogen receptor, for progesterone receptor, and for HER2 expression), and CTCs in general were mostly found to be triple-negative, regardless of the estrogen receptor status, progesterone receptor status and HER2 status of the primary tumor tissue.

Based on these data, one may speculate that the tumor biological features of CTCs and DTCs are quite different but, without validation in other breast cancer collectives, one should act with caution when using this information for the clinical management of breast cancer patients subject to adjuvant therapy.

Although potentially interesting, we would like to emphasize that the data presented by Fehm and colleagues [1] have to be discussed in the framework of the 2007 update of recommendations for the use of cancer biomarker tests, published by the American Society of Clinical Oncology regarding prevention, screening, treatment, and surveillance of breast cancer [2]. The Update Committee came to the conclusion that data available at that point were insufficient to recommend adjuvant therapy to a particular patient, if based only on the presence of bone marrow DTCs.

Because bone marrow may be a reservoir of latent micrometastatic cells [3], in the future the detection of DTCs

$\mathrm{CTC}=$ circulating tumor cell; $\mathrm{DTC}=$ disseminated tumor cell; $\mathrm{PCR}=$ polymerase chain reaction; $\mathrm{RT}=$ reverse transcriptase. 
in the bone marrow may become more important in the context of therapies such as bisphosphonates interfering with bone marrow-tumor cell interactions [4]. Although the measurement of CTCs in blood to influence treatment decisions is not yet ready for routine use, the 2009 St Gallen recommendations [5] recognized the potential of new technological advances to phenotypically characterize individual CTCs and the identification of therapeutic targets such as HER2. However, until additional validation would confirm the clinical value of existing test formats, and before CTC/DTC testing could achieve standard-of-care status, improvement in the sensitivity, precision, and reproducibility of the detection methods has to be provided, preferentially by multicentric prospective clinical trials.

Two different methods to screen bone marrow aspirates of breast cancer patients for DTCs are in use - namely, antibody-based cytologic/cytometric approaches and molecular approaches [6]. Most frequently, antibodies against certain epithelium-specific antigens such as cytoskeleton-associated cytokeratins, surface adhesion molecules, or growth factor receptors are applied for the detection of carcinoma cells [7]. As an alternative testing method, real-time RT-PCR-based protocols for DTC detection in the bone marrow of breast cancer patients have become available [8].

Similar to the enrichment and detection methods for DTCs, most of the techniques employed to detect and characterize CTCs rely on a combination of an ex vivo enrichment step by adding ferrofluids loaded with antibodies directed towards epithelial cell surface epitopes, such as EpCAM, and a detection step, utilizing a few milliliters of anticoagulated blood. For this, the USA Food and Drug Administrationapproved immunobead-based CellSearch CTC detection system is widely used [9], but alternative bead-based or chipbased sampling techniques are also in use [10-12].

The AdnaTest BreastCancerSelect/AdnaTest BreastCancerDetect kit (AdnaGen AG) used by Fehm and colleagues was developed for the enrichment of CTCs from peripheral blood of breast cancer patients, followed by detection of breast cancer-associated gene expression in immunomagnetically enriched tumor cells by reverse transcription and PCR [1]. The test is considered positive if a PCR fragment of at least one of the tumor-associated transcripts for EpCAM, for MUC1, or for HER2 is clearly detected. In spite of this, these transcripts can also be identified by sensitive RT-PCR assays in normal blood or tissues, and therefore clear cutoff values need to be defined and validated [10].

Unfortunately, the data of large-scale DTC/CTC validation studies, also addressing standardization and comparison of various DTD/CTC sampling and detection technologies, have not yet been reported. Recent meeting reports, however, disclosed concordance rates for data obtained with the CellSearch $^{\mathrm{TM}}$ test system (Veridex LLC, Raritan, NJ, USA) and with the AdnaTest BreastCancer ${ }^{\mathrm{TM}}$ kit of $68 \%$ and $88 \%$ $[1,13,14]$. A performance evaluation breast cancer study (BR-01-2004) to demonstrate this advantage of the AdnaTest BreastCancer ${ }^{\mathrm{TM}}$ kit as a new tool for decision guidance in cancer therapy over standard CTC detection methods is ongoing. A prospective German multicenter trial (DETECT) in metastatic breast cancer using both methods has also recently completed its recruitment, but data have not yet been published [1]. The same position is true for the SUCCESS trial, a German prospective multicenter breast cancer trial employing the CellSearch technique, to assess the value of CTCs in the adjuvant setting [15].

CTC/DTC testing seems to have significant future potential value in the identification of breast cancer patients at risk for disease recurrence, for stratification of patients to adjuvant therapies, and for therapy response monitoring [4,5]. Nonetheless, optimization and standardization of DTC/CTC detection techniques is highly needed, preferentially within prospective randomized clinical trials.

\section{Competing interests}

The authors declare that they have no competing interests.

\section{References}

1. Fehm T, Hoffmann O, Aktas B, Becker S, Solomayer EF, Wallwiener D, Kimmig R, Kasimir-Bauer S: Detection and characterization of circulating tumor cells in blood of primary breast cancer patients by RT-PCR and comparison to status of bone marrow disseminated cells. Breast Cancer Res 2009, 11:R59.

2. Harris L, Fritsche H, Mennel R, Norton L, Ravdin P, Taube S, Somerfield MR, Hayes DF, Bast RC Jr; American Society of Clinical Oncology: American Society of Clinical Oncology 2007 update of recommendations for the use of tumor markers in breast cancer. J Clin Oncol 2007, 25:5287-5312.

3. Zhang XHF, Wang Q, Gerald W, Hudis CA, Norton L, Smid M, Foekens JA, Massagué J: Latent bone metastasis in breast cancer tied to src-dependent survival signals. Cancer Cell 2009, 16:67-78.

4. Gnant M, Mlineritsch B, Schippinger W, Luschin-Ebengreuth G, Pöstlberger S, Menzel C, Jakesz R, Seifert M, Hubalek M, BielicRadisic V, Samonigg H, Tausch C, Eidtmann H, Steger G, Kwasny W, Dubsky P, Fridrik M, Fitzal F, Stierer M, Rücklinger E, Greil R; ABCSG-12 Trial Investigators, Marth C: Endocrine therapy plus zoledronic acid in premenopausal breast cancer. N Engl J Med 2009, 360:679-691.

5. Goldhirsch A, Ingle JN, Gelber RD, Coates AS, Thürlimann B, Senn HJ; Panel members: Thresholds for therapies: highlights of the St Gallen International Expert Concensus on the primary therapy of early breast cancer 2009. Ann Oncol 2009, 20:1319-1329.

6. Riethdorf S, Pantel K: Disseminated tumor cells in bone marrow and circulating tumor cells in blood of breast cancer patients: current state of detection and characterization. Pathobiology 2008, 75:140-148.

7. Lacroix M: Significance, detection and markers of disseminated breast cancer cells. Endocr Relat Cancer 2006, 13:10331067.

8. Becker S, Becker-Pergola G, Banys M, Krawczyk N, Wallwiener D, Solomayer E, Schuetz C, Fehm T: Evaluation of a RT-PCR based routine screening tool for the detection of disseminated epithelial cells in the bone marrow of breast cancer patients. Breast Cancer Res Treat 2009, 117:227-233.

9. Cristofanilli M, Budd GT, Ellis MJ, Stopeck A, Matera J, Miller MC, Reuben JM, Doyle GV, Allard WJ, Terstappen LW, Hayes DF: Circulating tumor cells, disease progression, and survival in metastatic breast cancer. N Engl J Med 2004, 351:781-791. 
10. Alix-Panabières $\mathrm{C}$, Riethdorf $\mathrm{S}$, Pantel $\mathrm{K}$ : Circulating tumor cells and bone marrow micrometastasis. Clin Cancer Res 2008, 14: 5013-5021.

11. Maheswaran S, Sequist LV, Nagrath $S$, Ulkus L, Brannigan $B$, Collura CV, Inserra E, Diederichs S, lafrate AJ, Bell DW, Digumarthy S, Muzikansky A, Irimia D, Settleman J, Tompkins RG, Lynch TJ, Toner M, Haber DA: Detection of mutations in EGFR in circulating lung-cancer cells. N Engl J Med 2008, 359:366377.

12. Pachmann K, Camara $O$, Kavallaris A, Krauspe S, Malarski N, Gajda M, Kroll T, Jörke C, Hammer U, Altendorf-Hofmann A, Rabenstein C, Pachmann U, Runnebaum I, Höffken K: Monitoring the response of circulating epithelial tumor cells to adjuvant chemotherapy in breast cancer allows detection of patients at risk of early relapse. J Clin Oncol 2008, 26:1208-1215.

13. Andreopoulou E, Urbauer DL, Krishnamurthy S, Reuben JM, Valero V, Cristofanilli M, Fritsche $\mathrm{H}$ : Comparison of circulating tumor cells (CTCs) in metastatic breast cancer (MBC): AdnaTest breast cancer for detection and biological characterization. AACR Meeting Abstracts 2008, 2008:A6.

14. Dirix LY, Elst H, Benoy I, Auw I Van der, Prové A, Wuyts H, Maes $H$, van Dam $P$, Huget $P$, Vermeulen $P$, Sint-Augustinus AZ: Circulating tumor cell detection: a direct comparison between the CellSearch system, the AdnaTest, and CK-19/mammaglobin RT-PCR in patients with metastatic breast cancer. J Clin Oncol 2009, 27(Suppl):e22117.

15. Schindlbeck C, Rack B, Jueckstock J, Schneeweiss A, ThurnerHerrmanns E, Schneider A, Rezai M, Beckmann M, Pantel K, Lichtenegger W, Sommer H, Friese K, Janni W, Chatsiproios D: Prognostic relevance of circulating tumor cells (CTCs) in peripheral blood of breast cancer patients before and after adjuvant chemotherapy - translational research program of the German SUCCESS-trial. San Antonio Breast Cancer Meeting 2008: abstract \#303. 